Pobrane z czasopisma Annales H - Oeconomia http://oeconomia.annales.umcs.pl Data: 26/04/2023 16:33:27

DOI:10.17951/h.2018.52.4.29-38

\begin{tabular}{lcc}
\hline \multicolumn{3}{c}{ A N N A L E S } \\
UNIVERSITATIS & MARIAE CURIE-SKŁODOWSKA \\
LUBLIN - POLONIA & \\
VOL. LII, 4 & SECTIOH H \\
\hline
\end{tabular}

University of Gdańsk. Department of Accounting of the Faculty of Management

\title{
JERZY GIERUSZ
}

ORCID ID: https://orcid.org/0000-0002-6693-9323

gierusz@wp.pl

MACIEJ GIERUSZ

ORCID ID: https://orcid.org/0000-0001-8374-6585

mac_gie@wp.pl

\section{Polish GAAP as Part of the Globalization Process}

Polska rachunkowość jako część procesu globalizacji

Keywords: harmonization; Polish GAAP; accounting models

Słowa kluczowe: harmonizacja; polska rachunkowość; modele rachunkowości

JEL code: M41

\section{Introduction}

After the 1989 elections, the Polish economy stepped onto the path of transformation leading to the free market model. This required restructuring the entire finance system of the country, including financial reporting of business entities. In the early 1990s, Polish Generally Accepted Accounting Principles (GAAP) were fully dominated by tax rules and unprepared to meet the needs of the development of the domestic capital market and ongoing globalization. The main aim of this article is to present the main streams of harmonization on the global scale and to comment on them in the context of the major changes Polish GAAP went through. The main thesis is that Polish GAAP evolved primarily under the influence of International 
Accounting Standards / International Financial Reporting Standards and European Union Directives, whose provisions were adapted to the local regulation. Consequently, the present Polish GAAP is a mixture of Anglo-Saxon and Continental models. The research methods used included studying professional literature and analysing legal acts. Since the article was written for the $17^{\text {th }}$ International Conference "Financial market - institutions and instruments 2018", its contents address in the first place readers from Eastern Europe whose economies currently face similar issues as Poland did in the 1990s.

\section{Trends in the harmonization}

In the course of evolving over the centuries, accounting developed two major streams/models - Anglo-American and Continental. Table 1 presents their features.

Table 1. Characteristics of the Anglo-American and Continental models of accounting

\begin{tabular}{|l|l|l|}
\hline \multicolumn{1}{|c|}{ Comparability criterion } & $\begin{array}{l}\text { Anglo-American model (including } \\
\text { the UK and USA) }\end{array}$ & \multicolumn{1}{|c|}{$\begin{array}{c}\text { Continental model (including } \\
\text { Germany and France) }\end{array}$} \\
\hline 1. Sources of regulation & $\begin{array}{l}\text { Standards developed by professio- } \\
\text { nal bodies }\end{array}$ & $\begin{array}{l}\text { Legal acts, laws, resolutions passed } \\
\text { by parliament }\end{array}$ \\
\hline 2. Relationship with tax law & Weak & Strong \\
\hline 3. Target readers of information & Owners - shareholders, investors & Creditors \\
\hline 4. Accounting policy & Wide scope of choice & Limited scope of choice \\
\hline 5. Measurement basis & Fair value & Historical cost \\
\hline 6. Underlying principle & True and fair view, matching & Prudence \\
\hline 7. Scope of disclosures & Broad & Limited \\
\hline
\end{tabular}

Source: Authors' own elaboration based on: Michalak [2002, pp. 353-363], Surdykowska [1999, pp. 62-67], Migała-Warchoł and Wlaz [2002, pp. 148-162], Jaruga [2002, pp. 18-21], Choi et al. [1999, pp. 57-80], Frost and Pownall [1994, pp. 75-102], Alexander and Archer [1995], Walton [1995].

The clash of globalization and the accounting models (including those presented in Table 1 and others) gave rise to harmonization. ${ }^{1}$ Jaruga stated it can be assumed that "harmonization of the accounting regulation on the regional or international level describes a process of increasing comparability of financial statements by implementing a set of pattern, based on common concepts and definitions defining at the same time limitations to the scope of diversity regarding solutions applied in practice" [Jaruga, 2002, p. 5].

Initially, the harmonization process was only present in the United States. The idea that was born at the $1^{\text {st }}$ International Accounting Congress in Saint Louis in 1904 led to the foundation of Committee on Accounting Procedures (CAP) in 1936. This was the first institution developing accounting standards, which were called

1 An overview of definitions for harmonization is included, among others, in: Surdykowska [1999, pp. 73-74], Krasodomska [2013, pp. 137-139], Błażyńska [2015, pp. 64-66], or Bek-Gaik [2013, pp. 68-72]. 
Accounting Research Bulletins. Altogether, 51 of them were issued. In 1959, CAP was replaced by the Accounting Principles Board (APB) that published 31 opinions (APB Opinion). Organisational changes were completed in 1973 when the Financial Accounting Standards Board (FASB) was set up. This body is still responsible for developing American Generally Accepted Accounting Principles - US GAAP [Gierusz, 2017, pp. 19-27].

In the second half of the $20^{\text {th }}$ century, efforts in the US found their reflection at the international level. The $10^{\text {th }}$ International Accounting Congress, which took place in Sydney in 1972, accepted the need to establish an international institution for harmonization. A year later, the International Accounting Standard Committee (IASC) was founded and was the body that developed 41 International Accounting Standards (IAS) [Ignatowski, 2012, pp. 235-238]. In 2000, the body was transformed into the International Accounting Standards Board, which up until the present day continues to issue its International Financial Reporting Standards (IFRS). IFRS provisions tend to be based on the Anglo-American accounting regulations.

The third trend of harmonization was initiated by setting up the Accountant International Study Group (AISG), which concentrated their efforts on developing uniform regulation at the European level [Ignatowski, 2012, pp. 332-335]. Their work later led to directives concerning accounting published by EEC and subsequently EU bodies. Since the contents of the directives were to certain extent influenced by Germany and France, the EU regulations bear some similarity to the Continental model.

Projects undertaken within the trends were as a rule carried out independently from each other, but sometimes they overlapped. In practice, this meant that regulations adopted by one body were accepted by another. This included:

1. Permission granted by the EU to entities listed on foreign stock exchanges to publish their financial reports in accordance with IAS or US GAAP (1995);

2. Endorsement of 30 International Accounting Standards (IAS) by the International Organization of Securities Commission (IOSCO) (2000);

3. Ratification of Ordinance No. 1606/2002 by the European Parliament and the European Commission requiring entities listed on any stock exchange in EEA (European Economic Area) to issue their consolidated financial statements in accordance with IFRS (2002); and

4. Approval given by the Securities Exchange Commission to use IFRS as the basis for preparation of consolidated financial statements by foreign entities (non-US filers) listed in New York (2007) [Gierusz, 2017, pp. 20-27; Kędzior, Krasnodomska, 2013, pp. 166-178].

An exceptionally important event for the harmonization process took place in 2002, when cooperation between IASB and FASB (the Norwalk agreement) began leading to preparation of the Road Map of Convergence in 2005. This document instituted joint efforts of the two bodies to eliminate fundamental differences between IFRS and US GAAP. This enabled: 
1. Publication of two chapters of the Conceptual Framework for Financial Reporting: "The aim of general purpose financial statements" and "Qualitative features of financial information"; and

2. Issuance of IFRS 13 "Fair value measurement".

\section{Evolution stages of Polish GAAP}

Until the end of the 1980s, accounting in Poland functioned outside the harmonization trends. The next decade was the start of an economic transformation leading to a free market economy, but accounting regulation continued to be shaped by tax law. The first document to change this was the Ordinance of the Minister of Finance dated 15 January $1991^{2}$ concerning accounting policies adopted by entities. The issuance of regulation was based upon provisions of the Tax Liabilities Laws. ${ }^{3}$ Polish GAAP has only been part of the harmonization since 1994. Those developments cover some key dates, including:

- 1994: ratification of the autonomous accounting regulation (the Accounting Act);

- 2002: narrowing the scope of differences to IAS/IFRS;

- 2005: obligatory adoption of IFRS by entities listed on the Warsaw Stock Exchange; and

- 2014 and 2015: adaptation of the Accounting Act to the requirements of the 2013/34/EU Directive issued by the European Parliament and the European Commission.

Ratification of the Accounting Act ${ }^{4}$ in 1994 was, on the one hand, a consequence of dynamic development of financial markets and on the other hand, resulted from the necessity to adopt EU Directives to the Polish law system. This especially applied to the $4^{\text {th }}$ Directive (78/660/EEC) dated 25 July 1978, concerning the annual accounts of entities and the $7^{\text {th }}$ Directive (83/349/EEC) dated 13 June 1983, covering consolidated financial statements [Gierusz, 2001, p. 5].

Introduction of the act enabled meeting several important targets:

- defining the key categories necessary for their performance evaluation, including equity, leasing, commercial papers, profit for the period, loan and others;

- setting the scope and contents of financial statements, emphasising the need of external audit; and

2 Journal of Laws 1991, No. 10, item 35 with subsequent changes.

3 See Article 38.3 of the Tax Liabilities Laws dated 19 December 1980 (Journal of Laws 1980, No. 27, item 111 with subsequent changes).

4 The Accounting Act was dated 29 September 1994 (Journal of Laws No. 121, item 591 with subsequent changes). 
- introducing the concept of accounting policy to allow entities a certain degree of flexibility when determining their accounting principles, especially in terms of costing and depreciation.

Consequently, there was a clear departure from tax rules enabling entities to show in their financial statements a true and fair view of their financial position and performance [Walińska, 2012, pp. 230-232].

The second step in the evolution of Polish GAAP was marked by the fundamental amendment of the Accounting Act, ${ }^{5}$ which became valid from 2002. Changes covered three areas:

1. Definitions of the key categories;

2. Measurement basis for assets and liabilities, which was a shift from a profit-driven to a balance sheet-driven perspective; and

3. The form and contents of financial statements.

The logic of the changes was primarily influenced by the IFRS regulation of that time. Poland was in the process of joining the EU, and adoption of the IASB solution was a natural consequence of that process.

The amended Accounting Act for the first time in the history of Polish accounting included fundamental definitions like "assets", "liabilities", "expenses", "losses", "incomes", "gains", "provisions", and "financial instruments". Criteria to distinguish between operating and finance leases were established. Completely new categories appeared, like business combinations, deferred taxation, construction contracts and investments in the sense of finance theory. Some of the definitions were revised: purchased (positive or negative) goodwill, tangible fixed assets, intangible assets.

In terms of measurement basis for assets and liabilities, some terms were provided with additional guidance: "purchase price", "net realisable value", and "production cost", including the necessity to distinguish between variable and fixed production overheads followed by determining the inefficient portion of the latter ones to be charged to profit. Fair value was introduced for the first time as a valuation alternative. Substantial changes were made to the form and contents of the balance sheet and the income statement, adding a new component of financial statements - a statement of changes in equity. Additional information to financials was extended by "Introduction to Financial Statements". Flexibility was further increased by allowing entities to follow IFRS guidance for areas not covered by the Accounting Act and Polish Accounting Standards [Orzeszko, 2002, pp. 404-406]. It may be concluded that the 2002 amendments were an important step to reducing the differences between Polish GAAP and IFRS, placing Poland in the mainstream of harmonization.

The Ordinance of the European Parliament and the EU Commission No. 1606/2002/EU, dated 9 July 2002, concerned the adoption of IFRS. Based on provisions of this document, consolidated financial statements of entities listed on the

5 Change of the Accounting Laws Act dated 9 November 2000 (Journal of Laws No. 113, item 1186 with subsequent changes). 
Stock Exchange in Warsaw as well as banks (even if not listed) need to be prepared in accordance with IAS/IFRS. The Polish Accounting Act is only applicable for those entities regarding areas not covered by IFRS such as frequency of stock take, keeping archives and formal aspects of evidencing transactions. Over time, it has become also allowed, depending on an entity's accounting policy, to adopt IAS/IFRS in subsidiaries that are part of a group that is obliged to use IFRS reporting on the consolidated accounts level. This resulted in a situation in which, as a rule, listed entities and their subsidiaries report based on international regulation, whereas unlisted and very often smaller local businesses need to follow the Polish Accounting Act.

The fourth step of the evolution is marked by two amendments of the Accounting Act dated 11 July 2014 and 23 July $2015 .{ }^{6}$ Both are a consequence of implementing the 2013/34/ EU Directive issued by the European Parliament and the EU Commission dated 26 July 2013 concerning annual financial statements, consolidated financial statements and related financial statements of entities. These regulations distinguish two new categories of entities:

1. "Micro" entities - primarily partnerships and limited liability entities that in the given financial year and in the previous period did not exceed two out of three amounts:

a. total assets of 1.5 million PLN;

b. total revenue from sale of goods and services of 3 million PLN; and

c. average headcount of 10 ; and

2. "Small" entities - primarily partnerships and limited liability entities that in the given financial year and in the previous period did not exceed two out of three amounts:

a. total assets of 17 million PLN;

b. total revenue from sale of goods and services of 34 million PLN; and

c. average headcount of 50 .

Both these categories were granted the right to make far-reaching simplifications in terms of measurement and disclosure. The first group of entities is no longer obliged to apply fair value and amortised cost valuation or to carry out impairment review and set up provisions. Financial statements are reduced to an abbreviated balance sheet and income statement prepared using natural classification of expenses [Dadacz, 2014, pp. 2-5]. Small entities may classify leasing arrangements based on the tax regulation and do not have to recognize deferred tax or measure the inefficient portion of fixed production overheads when costing products. Their financial statements pro forma are also simplified (see attachment No. 5 to the Accounting Act).

6 Amendment to the Accounting Law Act dated 11 July 2014 (Journal of Laws 2014, item 1100), amendment to the Accounting Law Act and other laws dated 23 July 2015 (Journal of Laws 2015, item 1333). 
Based on these considerations, it can be concluded that Polish regulations are subject to constant evolution while at the same time being the two main streams of harmonization driven by the IASB and the European Union Directives.

\section{Distinctive features of Polish GAAP}

1. Sources of the accounting law. Its basis is the Accounting Act followed by the numerous ordinances based on the act that are issued by the Minister of Finance. However, increasing importance must be attached to the National Accounting Standards (KSR) and Committee Statements developed by the Accounting Standards Committee in close cooperation with accounting professionals and business.

2. Overlaps with tax regulations. There are areas in which accounting and tax regulation are uniform, covering, for example, calculation of forex gains and losses, establishing the first cost of a fixed asset or an option to follow certain tax regulation as a part of an entity's accounting policy. This could include choosing the same depreciation rates and methods for fixed assets and intangibles. At the same time, the scope of accounting law's autonomy is significant and covers provisions, impairment tests and investment properties. These categories are not allowed under tax rules.

3. Main users of financial information. Polish regulation does not specifically define who the target reader of financial information is. It can, however, be assumed that they are owners/shareholders as well as other capital providers/ lenders.

4. Accounting policies. Regulation offers a limited choice. Discretion relates primarily to cost allocation, depreciation, adoption of FIFO, LIFO or weighted cost. For issues that remain outside the scope of regulation by the Accounting Act, entities are free to follow IFRS. It has been, however, prescribed in detail what the pro forma of financial statement components is and how to evidence economic transactions, keep archives and protect data.

5. Measurement of elements of financial statements. Valuation is still dominated by the historical cost, which relates in the first place to fixed assets, intangible assets and biological assets. At the same time, the scope of fair value application increases, including financial assets and liabilities, investment properties and business combinations.

6. Underlying assumptions. The Accounting Act refers to the True and Fair View as well as the Matching Principles that are key characteristics of the Anglo-American model. It also mentions prudence, which is associated with the Continental model.

7. Scope of disclosures. Accounting Act requirements appear to be moderate. They are not as detailed as prescribed by individual IAS/IFRS, but by defin- 
ing elements of financial statements and the scope of additional information presentation and disclosures are consistent, structured in their logic with an option to include more information.

\section{Conclusions}

Analysis carried out by the authors enables forming the following conclusions:

1. Transformation from a planned to a free market economy and ongoing globalization processes represent the major forces shaping developments withrespect of Polish GAAP, which took place in the 1990s. Trends were set by two sources of international regulation, IAS/IFRS and the European Union Directives. This enabled separating accounting law from tax law and converting it into an autonomous regulation.

2. Polish GAAP evolves in the direction proposed by the IASB. At the same time, Poland as an EU member had to implement the EU directives. Consequently, Polish accounting regulation represents a mixed model including the influences of both Anglo-American and Continental models.

3. Ongoing harmonization on both global and regional levels resulted in lack of comparability of financial statements in the local scale. Currently in Poland, there are four groups of entities with varying legal basis for bookkeeping as well as scope and detail level in terms of financial reporting:

a. groups listed on the stock exchange, which follow IAS/IFRS; and

b. other entities that follow to more or less extent the Accounting Act:

i. micro;

ii. small; and

iii.big.

4. Gradually increasing importance can be attributed to the National Accounting Standards and Statements of the Accounting Standards Committee. They represent "good practice", explaining the most sophisticated accounting issues concerning recognition, measurement and presentation of specific balance sheet items.

5. Further research in the analysed area could focus on assessing the consequences of lack of comparability of financial statements in Poland and investigating opportunities to extend the application of IFRS to entities other than those listed on the Stock Exchange in Warsaw. 


\section{References}

Accounting Act dated 29 September 1994 (Journal of Laws, 1994, No. 121, item 591 with subsequent changes).

Alexander, D., Archer, S., European Accounting Guide, Harcourt Brace Jovanovich, San Diego 1995.

Amendments to Accounting Laws Act dated 9 November 2000 (Journal of Laws, 2000, No. 113, item 1186).

Amendments to Accounting Laws Act dated 16 December 2005 (Journal of Laws, 2005, No. 267, item 2252).

Amendments to Accounting Laws Act dated 11 July 2014 (Journal of Laws, 2014, item 1100).

Amendments to Accounting Laws Act dated 23 July 2015 (Journal of Laws, 2015, item 1333).

Bek-Goik, B., Sprawozdawczy wymiar rachunku wyników w warunkach globalnego rynku, Wydawnictwo Uniwersytetu Łódzkiego, Łódź 2013.

Błażyńska, J., Użyteczność informacji finansowych sprawozdań finansowych, Wydawnictwo Uniwersytetu Ekonomicznego w Poznaniu, Poznań 2015.

Choi, F.D.S., Frost, C.A., Meek, G.K., International Accounting, Prentice Hall, New Jersey 1999.

Dadacz, J., Uproszczenia rachunkowości jednostek „,mikro”, „Rachunkowość” 2014, No. 9.

Frost, C.A., Pownall, G., Accounting Disclosure Practices in the United States and the United Kingdom, "Journal of Accounting Research" 1994, Vol. 32(1).

Gierusz, J., Założenia koncepcyjne sprawozdawczości finansowej, [in:] J. Gierusz, M. Gierusz (red.), Międzynarodowe Standardy Sprawozdawczości Finansowej w teorii i praktyce, ODDK, Gdańsk 2017.

Gierusz, J., Zmiany w ustawie o rachunkowości 2001/2002, ODDK, Gdańsk 2001.

Ignatowski, R., Początki i rozwój światowej harmonizacji rachunkowości - droga do powstania IASC, [in:] I. Sobańska, P. Kabalski (red.), Współczesne nurty badawcze w rachunkowości, Wydawnictwo Uniwersytetu Łódzkiego, Łódź 2012.

Jaruga, A., Systemy regulacji rachunkowości a międzynarodowa harmonizacja i standardyzacja, [in:] A. Jaruga (red.), Międzynarodowa regulacja rachunkowości, C.H. Beck, Warszawa 2002.

Kędzior, M., Krasodomska, J., Unia Europejska i dyrektywy z zakresu rachunkowości, [in:] K. Grabiński, M. Kędzior, J. Krasodomska (red.), Globalne uwarunkowania rachunkowości, PWE, Warszawa 2013.

Krasodomska, J., Standardyzacja, harmonizacja, unifikacja czy konwergencja, [in:] K. Grabiński, M. Kędzior, J. Krasodomska (red.), Globalne uwarunkowania rachunkowości, PWE, Warszawa 2013.

Michalak, M., Globalizacjaa kształt systemów rachunkowości, [in:] J. Gierusz, M. Jerzemowska, T. Martyniuk (red.), Rachunkowość wobec procesów globalizacji, Wydawnictwo Uniwersytetu Gdańskiego, Gdańsk 2002.

Migała-Warchoł, A., Wlaz, R., Specyfika systemu rachunkowości krajów reprezentujących model anglosaski i kontynentalny na przykładzie Stanów Zjednoczonych Ameryki i Niemiec, [in:] A. Kaszuba-Perz, E. Nowak (red.), Znowelizowana ustawa o rachunkowości w świetle Międzynarodowych Standardów Rachunkowości, Wydawnictwo Wyższej Szkoły Informatyki i Zarządzania w Rzeszowie, Rzeszów 2002.

Ordinance of the Minister of Finance dated 15 January 1991 concerning accounting policies adopted by entities (Journal of Laws, 1991, No. 10, item 35 with subsequent changes).

Orzeszko, T., Reforma polskiej rachunkowości jako przejaw globalizacji, [in:] J. Gierusz, M. Jerzemowska, T. Martyniuk (red.), Rachunkowość wobec procesów globalizacji, Wydawnictwo Uniwersytetu Gdańskiego, Gdańsk 2002.

Surdykowska, S.T., Rachunkowość międzynarodowa, Zakamycze, Kraków 1999.

Tax Obligations Act dated 19 December 1980 (Journal of Laws, 1980, No. 27, item 111 with subsequent changes).

Walińska, E., „Kroki milowe” w rozwoju polskiej regulacji rachunkowości w warunkach gospodarki rynkowej, [in:] J. Sobańska, P. Kabalski (red.), Wspótczesne nurty badawcze w rachunkowości, Wydawnictwo Uniwersytetu Łódzkiego, Łódź 2012.

Walton, P., European Financial Reporting: A History, Academic Press, London 1995. 
Pobrane z czasopisma Annales H - Oeconomia http://oeconomia.annales.umcs.pl

Data: 26/04/2023 16:33:27

\section{Polska rachunkowość jako część procesu globalizacji}

W artykule opisano rozwój polskiej rachunkowości od początku lat 90. XX w. do dnia dzisiejszego w kontekście harmonizacji. Wyjaśniono, że zmiany były kształtowane przez dwa źródła międzynarodowych regulacji: MSSF i dyrektywy Unii Europejskiej. W efekcie polska rachunkowość reprezentuje model mieszany, łącząc w sobie cechy zarówno rozwiązań anglo-amerykańskich, jak i kontynentalnych.

\section{Polish GAAP as Part of the Globalization Process}

The article describes the evolutionary stages of Polish GAAP from the early 1990s to the present day in the context of basic harmonization trends. It explains that the developments have been shaped by two groups of international regulation, IFRS and the European Union directives. As a result, Polish GAAP represents an example of a mixed model accounting including features of both Anglo-American and Continental regulation. 